Deliberation, Dialogue or Dissemination

Changing objectives in the communication of science and technology in Denmark

Horst, Maja

Published in:

Science Communication in the World

DOI:

10.1007/978-94-007-4279-6

Publication date:

2012

Document version

Early version, also known as pre-print

Citation for published version (APA):

Horst, M. (2012). Deliberation, Dialogue or Dissemination: Changing objectives in the communication of science and technology in Denmark. In B. Schiele, M. Claessens, \& S. Shunke (Eds.), Science Communication in the World: Practices, Theories and Trends (pp. 95-108). Springer. https://doi.org/10.1007/978-94-007-4279-6 


\title{
Deliberation, Dialogue or Dissemination: changing objectives in the communication of Science and Technology in Denmark
}

Maja Horst, University of Copenhagen

\begin{abstract}
:
The chapter provides an introduction to the Danish landscape of science communication which is build on a deeply rooted culture of equality and anti-elitism. Within this cultural tradition, citizens have a moral right to question the testimony of authorities and to counter it with their own experiences of ordinary life. The tradition is described by a short introduction to one of its most influential proponents, the nineteenth century priest, poet and politician, NFS Grundtvig, who promoted a particular educational philosophy in which citizens through deliberation were expected to be able to reach consensus about the life to lead in common. The teachings of Grundtvig were an important factor in the establishment of the Danish deliberative institutions, such as the Danish Board of Technology and the Danish Council of Ethics, but the same anti-elitism has also been invoked in arguments to close them down. Through a description of how a change in government in 2001 had significant negative impact on these institutions, it is demonstrated that the development of science communication in Denmark is less straightforwardly focused on dialogue and deliberation than many outside commentators would believe. While the engagement agenda has been growing in other countries after the turn of the millennium, Denmark has moved in the opposite direction towards a more traditional deficit model of public understanding of science. A legislative change in 2003 made it mandatory for universities to conduct outreach and science communication. Simultaneously, Danish universities increasingly find themselves in competition for resources, such as funding and wellqualified staff and students. In this situation, science communication is becoming an important ingredient of organizational branding. The chapter concludes with a discussion of how individual research managers in bio- and nanotechnology have adapted to this situation and how they describe their own communication practice.
\end{abstract}

Keywords: Anti-elitism, Branding, Consensus Conferences, Danish Board of Technology, Danish Council of Ethics, Deliberation, Deficit model, Grundtvig, Institutionalization, Research Managers 
In 2002, the EU-funded STAGE-network (Science, Technology And Governance in Europe) had its introductory meeting in Copenhagen. The network consisted of researchers from eight European countries interested in studying the governance of Science in the light of recent more deliberative turns. In line with the general trend in the study of public communication of science and technology, the normative underpinnings for the network was a notion that science communication should be understood as a two-way process, where the objective was not just to educate the public about science, but also to involve publics and citizens in the governance of science through dialogue about objectives and regulation (STAGE, 2005).

Besides marking the beginning of the network period, the 2002 STAGE-workshop in Denmark was supposed to provide insight into the particular Danish form of participatory governance of science and technology, which has been epitomized by the Danish Style consensus conferences(Andersen \& Jæger, 1999; Klüwer, 1995; Seifert, 2006). It was therefore not a surprise that the agenda for the workshop included a presentation by Lars Klüwer, the director of the Danish Board of Technology, who was scheduled to talk about the work of the board. However, the surprise came when Lars Klüwer rose to speak and announced that he had just had a message that the government was going to close down the Board as part of a restructuring of a number of advisory bodies. He therefore had to leave immediately.

The present chapter will give a short introduction to the particular Danish form of science governance and science communication, but it will also look at the background to the announcement of the closure of the Board of Technology. The argument will be that both of these features are deeply rooted in specific aspects of Danish culture and that the development of science communication in Denmark is less straightforwardly focused on dialogue and deliberation than many outside commentators would believe. On this basis, the chapter will give a description of the current framework for communication of science and technology and discuss the heterogenous forces that influence current scientists, when they engage in science communication. In this way, the Danish case story tells us something about the intersections between science communication and broader cultural traits, and it also demonstrates how developments in science communication within a national framework can be very heterogeneous.

\section{A dialogue culture based on equality and anti-elitism}

The announcement of the intention to close the Board of Technology in 2002 came after an (in)famous New Year's speech made by the prime minister, Anders Fogh Rasmussen. 
Following a decade of centre-left governments led by the socialdemocratic party, Rasmussen's conservative and neoliberal alliance came into power in autumn 2001 based on support from the right-wing, anti-immigration party. For the first time in decades, the parliamentary majority did not need to be sought across the middle of Danish politics and Rasmussen declared the 'battle of values' a political priority. This battle was in focus in his first New Year's speech in 2002 and among other things he called for a "confrontation [or showdown] with the arbiters of taste". He announced that the new government intended to close a number of expert committees:

Many of them have evolved into state authorised arbiters of taste, who decide what is good and right in different areas. There are tendencies towards a tyranny of experts, which threatens to oppress the free public debate. The public should not have to submit to raised fingers from so-called experts who think they know best. (Rasmussen, 2002)

When making this speech, the prime minister was referring to deeply held cultural values in Denmark, which is best explained through a small historical detour to the teachings of one of the most influential cultural figures in Denmark, the priest, poet and politician N.F.S.Grundtvig (1783-1872) (See also Horst \& Irwin, 2010). Inspired by German idealism and British liberalism, Grundtvig was an active proponent of the creation of a nation state in which the Danish people would be united in a common history and a common mother tongue (Korsgaard, 2004). For this purpose, he devised a special institution, the 'folk high schools', whose task was education in knowledge about practical human life. The folk high schools were intended to be a school for life' where 'the living word' would transform young people into citizens and members of a Danish people with a shared culture and a common destiny. He envisioned them much more important for society than the universities, which he perceived as teaching 'dead' knowledge to individual scholars (Knudsen, 2001:99-105). Grundtvig was fiercely opposed to one-way teaching and envisioned folk high schools as open and anti-authoritarian institutions dedicated to the achievement of educational dialogue. His ideal of dialogue was founded in a belief that 'the living word' would transform both teacher and student and unite them in a sense of shared culture (Korsgaard, 2004:225-7).

Grundtvig had an explicitly anti-elitist perception and regarded the ordinary people as far more knowledgeable about the common life of man than any of the authorities in society (Knudsen, 2001:104). Knowledge, in his perception, came from experience of an ordinary life, shared culture and a common destiny as members of the nation state community. In one of his songs an often-cited line reads: "And the sun rises with the farmer, not at all with the learned"i (Grundtvig, 1839). Ordinary folk (and in particular farmers) were seen as better connected with the knowledge of practical life than learned people in universities. They should therefore not listen to authorities and think that elites knew better than them. Rather they should find their own standpoints through common deliberation among each other. 
The folk high schools became an integrated, although informal, part of the Danish educational system, as it became common for young people (particular from the countryside) to spend a year at a folk high school before they settled into more adult life. The educational ideals of these schools were based on dialogue and community building, and the schedule would include practical topics as well as issues of general enlightenment. Following industrialization and the development of new urbanized life-forms, the educational content in the folk high schools progressed, but the core objective has continued to be the development of democratic skills and identities of the students (Korsgaard, 2004). As Mejlgaard summarizes the influence of folk high schools:

As such, the people's high schools have been influential beyond providing training in S\&T skills by promoting a wider discourse of 'active humanism' (...), by institutionalizing a principle of 'life-long learning', which has become very important in Denmark, and by stimulating an environment of active appropriation of science and technology in a Danish context (Mejlgaard, 2009:488)

The teachings of Grundtvig and the backdrop of the folk high schools was an important factor in the anti-authoritarian, left-wing critique of science and technology which developed in the aftermath of the student revolts in the late 1960s in Denmark: 'A large part of these oppositional arguments drew upon a challenge to modernity, industrialisation, capitalist exploitation and - not least - hierarchical antagonism' (Horst \& Irwin, 2010). Grundtvig was evoked as a founding father of a culture in which experts were envisioned to be no more competent in making decisions about the life to be led in common than socalled lay people. Technical experts were often described as having a particular interest in the development of a technology and they were therefore less able to speak for the common good, than citizens with no specific, or vested, interest in the issues. In this way, Grundtvigs anti-elitism and his distinction between the dead knowledge of universities and the shared knowledge about common life developed through dialogue was explicitly invoked as a foundation for the discussion of public engagement with science and technology.

\section{The institutionalization of an engagement culture}

Prior to the early 1970 s direct public participation in science and technology policy had been modest if not completely absent (Mejlgaard, 2009). However, the oil crisis in 1973 led the Danish government to publish a nuclear program, which suggested the construction of nuclear power plants in Denmark. This sparked an intense public debate and generated wide-spread NGO activity around the energy issue. Grass-root organizations were making practical experiments with alternative energy, such as wind power and biogas, and they were also very actively engaged in knowledge production around alternative energy. In this way they were 'laying a foundation for what would later become a profitable Danish 
alternative energy industry' (Mejlgaard, 2009:489). The widespread public debate on nuclear energy came to a conclusion in 1982 when a referendum led to the abandonment of nuclear power in Denmark, but public discussions about energy systems and environmental issues persisted.

It was on the basis of these developments that the 1980s saw a more deliberative turn in Danish science governance. Inspired by National Institute of Health and the Office of Technology Assessment in the US, the first Danish consensus conference was arranged in November 1983. It focused on early diagnosis of breast cancer and was arranged in collaboration between the Danish medical research council and a public research organization called DSI (Danish Health Institute). Although it was inspired by the US, the Danish version was less intended to focus on the relationship between research and clinical practice and more directed at the connection between science and the public. An evaluation report of the first consensus conference states that it was intended to help promote "democratic decisions" and "competent judgments in the common interest [...] on the basis of constructive interaction between experts and non-experts" (Agersnap, Jakobsen, \& Kempinski, 1984:7).

Torben Agersnap, who was leading the evaluation, had a background in organization studies and he and his colleagues had worked extensively on democracy and participatory processes in work places. In his Department of Organization and Work Sociology at Copenhagen Business School, a number of researchers were engaged in the study of democratic approaches to technology (Agersnap, 1992). Besides the Grundtvigian influence, these approaches were also supported by the Danish trade unions, who promoted the workers' participation in technological decisions and the introduction of technology in the working place (Cronberg, 1995). What was later to be known as the specific Scandinavian 'participatory design' tradition in studies of Information Technology was based specifically on two assumptions: a) that the involvement of users will make better systems and reduce the risk of resistance to change, and $b$ ) that democracy is a goal in itself (Vikkelsø, 2003:31). In this way the Grundtivigian ideals were merged with the objectives of the trade unions and the merger were documented and encouraged by organizational scholars who made a strong case for the development of participatory engagement with technology (Joss \& Durant, 1995).

This background, as well as general expectations of major future change brought about by emerging information- and biotechnology led to demands for a more institutionalized way of dealing with new technology and its effects on society, organizations and individuals (Lassen, 2004). The result was suggestions to parliament that Denmark should follow the example of other countries and create a public body which could foster and develop public debate and assessment of emerging technologies. But politicians did not simply want to copy a solution from other countries. Rather they wanted a specifically Danish model derived from the Danish democratic tradition of equality and dialogue (Klüwer, 1995: 41). Consequently, in 1985 the first version of the Danish Board of Technology was decided by 
parliament. Its objectives were to "follow and initiate comprehensive assessments of the possibilities and consequences of technological development for society and citizens [as well as] support and encourage a public debate on technology" (Klüwer, 1995:41).

The Board was intended to be an inclusive force and to encourage interactions between a number of different stakeholders in society. It was organized with a secretariat that takes care of daily operation while a board of governors is responsible for directions and strategic decisions. Finally, a board of representatives from a large number of different public, private and third sector organizations serve as a group of important mediators to stakeholders. During its years of operation, the Board has developed a number of specific formats for technology assessment, including expert reports, but the specific format of the participatory consensus conference is most widely known (Einsiedel, Jelsøe, \& Breck, 2001; Horst, 2008; Seifert, 2006).

The 1980s, however, also saw the birth of a different body designed to assist political decision-making and encourage public debate about technology. The Council of Ethics, however, did not grow out of discussions of participatory technology assessment, but rather out of the controversies surrounding reproductive medical technology which gained momentum in the beginning of the 1980s. The controversies were sparked by the fact that fetal diagnostics had been a standard offer in the Danish health care system after 1977 as well as by the birth of the first Danish IVF baby in 1983. The combination of the technical possibilities in these techniques as well as images of cloning and genetic engineering led to many public speculations about designer babies and a general fear of erosion of moral norms.

In 1984 a report on the social and political responses to these new technical options were published and it suggested the formation of a Council of Ethics. The assumption in the report was that it was possible to achieve consensus about the regulation of biomedical technologies through deliberation among people who due to their professional experience and personal integrity could speak for the 'common human condition' (Koch \& Horst, 2007). Although this suggestion received immediate widespread support from policy makers, it took the Danish parliament 2 years to agree on the composition and mandate of such a body. In the resulting law it was stated that the council should make recommendations to policy-makers and health authorities as well as follow and initiate public debate about ethical issues.

During the parliamentary discussion about its formation, a crucial issue was the forms of knowledges and competences to be represented in the Council. Several attempts had been made at specifying the types of expertise that members of the Council should possess (Lund \& Horst, 1999). In the resulting law, however, it was just specified that the minister would appoint half of the members on the basis of the general knowledge about relevant ethical, cultural and social aspects, and a particular committee in parliament should appoint the other half. In practice, members have been medical experts as well as 
people with ethical, social, judicial and religious expertise. It also seems that members are appointed to represent a broad spectrum of opinions on the ethical issues.

Another point of discussion in the parliamentary negotiations about the council was the value foundations for the work of the council (Kappel \& Lykkeskov, 2007). When the legislation was finally approved in 1986, the small Christian democratic party had managed to insert an introductory clause that the Council should base its work upon a belief that life begins at procreation although this line was clearly at odds with the Danish legislation on abortion. This small addition can be seen to point to a major fault line in the debates in the council. As it turned out most of the policy advice from the council have been marked by disagreement and majority/minority recommendations (Koch \& Horst, 2007), and often disagreement on the status of the fetus has been the basis for these conflicts.

Compared to the Board of Technology, the Council of Ethics must be regarded as an expert committee, although the unspecific definitions of the kinds of expertise the members were expected to have, has been criticized (Kappel \& Lykkeskov, 2007). In addition to its expert status, however, it is explicitly stated in its legislative foundation that the Council had an obligation to generate public debate. Throughout its history, the Council has therefore not only produced reports of advice to politicians, but also arranged numerous open meetings, conferences, web-forums and other engagement activities to elicit public debate and opinion formation about new biotechnologies. And due to its history of split recommendations, it is probably in its role as initiator of public debate, that the Council has had most influence on the governance of science and technology in Denmark.

It is an interesting observation, that the parliamentary processes around the creation of the Board of Technology and the Council of Ethics took place in the same years, but without any visible interference. One reason for this lack of connection can be found in the fact that they were answers to questions about technological development raised from two different bodies of knowledge. The Board of Technology partly grew out of the focus on participatory design of new technology and deliberative democracy in workplaces and was primarily focused on Information technology and questions of environment and energy. The Council of Ethics, on the other hand, grew out of controversies around medical ethics and the wider impact on societal norms by medical technology. Another difference is that the Board of technology engaged researchers in organization and democracy as well as workplace and environmental activists in a shared knowledge production around participatory technology assessment. In contrast the Council very much epitomized a controversy between medical doctors and scientists who were in favour of the use of the new technologies, and social scientists, ethicists and religious scholars who were opposed to the use of the same technologies.

Despite these differences, however, it should be noted that they both embody a strong ideal about deliberation and engagement which has often been explicitly based on the 
cultural tradition developed on the basis of Grundtvig's writings. In the participatory consensus conferences, for instance, the citizens take centre stage. It is their task to listen to the testimony of the experts and then decide which aspects of this testimony are relevant for a shared understanding of the technology and a consensus agreement on its future development. The Board therefore makes a specific effort to identify the right type of citizen: on a general level they should be engaged and interested in the issue at hand, but they should not have specific, vested, interests. Strong previous engagement or specialist knowledge in the field is not an advantage for an ideal member of the citizens' panel in a consensus conference. In this way, the participatory consensus conferences build directly on the Grundtvigian ideal of the common sense of the ordinary man (Horst \& Irwin, 2010).

Similarly, the Council of Ethics was founded on an expectation that people with different opinions would be able to reach consensus through deliberation based on experience of the common human condition. And although the Council must be described as an expert body, the expertise of its members was not bound to a specific academic set of skills but rather to more general competencies developed through professional experience and personal integrity. In this way, it can be argued that Grundtvigian ideals have had a strong influence on the governance of science and technology in Denmark. Furthermore, since dialogue and deliberation feature so strongly in this form of governance, the communication of science and technology has been an implicit part of these governance structures. The important characteristic of the Danish model, however, is that public understanding of science was not seen to be solely a question of diffusion of knowledge, but rather part of a larger culture of debate and enlightenment. Science communication was not just a question of dissemination, but part of a larger process of sharing knowledge about the life to be led in common.

\section{Institutions in decline: the reinvention of PUS}

The Danish model has been an inspiration in other countries as they have sought to develop more participatory forms of public engagement with science (House of Lords select committee on science and technology, 2000). However, seen from the inside, the foundational institutions in the Danish model seem to have lost their momentum. Ironically, the 2001 prime ministerial speech about 'tyranny of experts' used the anti-elitist elements of Danish culture to argue against bodies including the Board of Technology, which epitomizes the free debate between citizens, but this incongruity was lost in the general 'battle about values'. In general, however, the announcement of the decision to close the Board of Technology was not the first blow to the institutions of public engagement. Funding had withered since the 1990s (Lassen, 2004) and media attention and support for the activities of the institutions also seemed to diminish (Lund \& Horst, 1999).

Consequently, as the engagement agenda seemed to grow in other countries, Denmark 
moved in the opposite direction towards a more traditional public understanding of science agenda. As one observer has put it:

"In the 2000s, however, public participation seems to have lost its status as the dominant tool for holding science and technology accountable to society. A new 'fiscal' regime of public accountability is rapidly gaining momentum, and meanwhile, policies on science and society increasingly support strategies of science dissemination and public education rather than public participation" (Mejlgaard, 2009:484)

In 2003 the Danish law on university governance was revised and it introduced an obligation to disseminate knowledge as a third mission of the universities (Videnskabsministeren, 2011). In the commentaries to this change it was clear that the ambition was to increase the application of knowledge in order to foster increased innovation in companies and improve the performance of the Danish knowledge economy. The minister also appointed a think tank on public understanding of science with a mandate to suggest policies on science communication in order to "give the Danish population an understanding of the importance of this area for our future welfare, environment, health and growth" (Ministry of Science, Technology, and Innovation, 2004 here cited from Mejlgaard, 2009). The mandate was connected to the general objective of increasing innovation through dissemination of applicable knowledge, but there was also a specific worry about the declining numbers of youngsters choosing to be educated in science and engineering.

The mandate quite straightforwardly builds on a deficit-model of public understanding of science (Irwin \& Wynne, 1996), but it is unclear how much the decision to establish the think tank was fuelled by a sense that public scepticism towards, for instance biotechnology, might be a roadblock to the innovation agenda. In this context, it should be noted, that a number of consensus conferences on biotechnology and numerous other engagement activities had not had the consequence that Danes were less sceptical about biotechnology than their European neighbours around the turn of the millennium (Suine \& Mejlgaard, 2001). However, the development in public opinion prior to this time is impossible to describe, as knowledge about public attitudes was not collected in any systematic fashion before the establishment of the Center for Studies in Research and Research Policy at Aarhus University in the late 1990s. This centre predominantly employed political scientists and among other things it has been responsible for the Danish Eurobarometer surveys.

The 2003 think tank on public understanding of science had 23 members of which 8 were from the mass media, 2 were from universities ( 1 of which were a communication director) and the rest was from public and private organizations with an interest in knowledge dissemination. Interestingly, nobody from the Board of Technology or the Council of Ethics were part of the think tank, just as none of the researchers previously involved in research 
on science communication or public understanding of science was included. Although the final report by the think tank did mention the Board of Technology, it appears more or less totally oblivious to the Danish tradition of engagement with science. The report introduces the value of dialogue and two-way communication of science, but subsequently focuses a great deal on mass media, without explaining how they can increase dialogue (Videnskabsministeriet, 2004).

Several of the suggestions made by the think tank has later been implemented in the first decade of the new millenium, such as a research communication prize, funds for research and experiments in science communication, an annual festival of research, an internet portal for science communication, and a special task force for communication of science to children. But neither the Board of Technology nor the Council of Ethics has gained former strength. The Board managed to fight off the threat of closure by mobilizing substantial support among supporters nationally and internationally (Mejlgaard, 2009), but their funding is sparse. The last consensus conference was held in 2005 and this only happened because the Board received funding from international sources.

Meanwhile, the introduction of the obligation to disseminate knowledge as well as an increasing sense of competition between Danish universities have led them to strengthen their professional capabilities within communication. Researchers are offered courses in science communication and most universities also have communication units which help disseminate stories about research results and new research projects. The result of the developments in the beginning of the new millennium is therefore a change in the general framework for science communication. Systematic science communication is now less connected with the institutions of democratic participation and more connected to the branding of organizations and research groups. This framework has also influenced the context for the individual scientists and their efforts to communicate publicly about their knowledge production.

\section{The role of the individual scientist}

Before 2003 , science communication by publicly employed scientists was completely based on individual initiative. There was no formal obligation to do so, just as scientists would not expect the university to have an opinion about how they chose to organize their communication activities as long as they stayed within the general professional norms of science. Science communication would therefore be undertaken by individuals who found it worthwhile to the extent that they had the ability to catch the attention of an audience. Sometimes scientists' communication activities would be part of the particular institutions mentioned above, such as the folk high schools and the consensus conferences, but Danish scientists have also used books, newsmedia and public meetings (Kragh, Kjærgaard, Nielsen, \& Nielsen, 2008). It should not be underestimated that the Grundtvigian tradition has not been unique in shaping communication of science and technology and a 
large part of the communication activities by scientists have been guided by a traditional ideal of dissemination similar to what is found in many other countries (Gregory \& Miller, 1998)

Following the change in the university law, the organization of science communication is slowly changing. It is no longer exclusively left to individual initiative as universities now have strategic interests in the nature and extent of communication activities. Danish universities are increasingly finding themselves in competition with each other and science communication has become an ingredient in the organizational branding. Also individual researchers and research groups find that visibility might increase their ability to attract resources such as funding and well-qualified staff.

In order to discuss how the changing circumstances influence researchers' behaviour and sense-making in relation to science communication, the following section will draw on a specific analysis of the communication practices of research managers in bio- and nanotechnology (Horst, under review). The analysis is based on 20 semi-structured interviews with research managers in bio- and nanotechnology. The interviews were conducted as part of a research project on research management, communication and risk and they were focused on the informants' views on their own communication activities and those of the people in their research group. The overall impression from these interviews is that there is great variation in the perception of science communication and the extent to which it is viewed as a strategic activity among the informants. Overall, the research leaders perceive the objectives of communication activities in three different ways corresponding to three different modes of science communication.

First of all, there is communication on behalf of a discipline. When researchers communicate in this mode they represent a certain body of knowledge and they speak as experts in a particular field. Their goal is to share their expertise with an audience which is often perceived as a target group with a certain set of characteristics. When communicating in this mode, some informants find it useful to utilize the services of the communication professionals at their university, while others do not. The practice of communicating in this mode is very much perceived as something that comes with the job. As part of a community of expertise it is expected that one shares ones knowledge. This is also how the younger researchers are expected to learn. Just as they have to acquire a number of other skills to grow into independent researchers, they have to learn how to talk to different target groups and these skills are acquired as part of the collective work that takes place in the group.

Secondly, there is communication, which is undertaken more as a representative of the entire institution of science. Scientists who reflect on their own communication activities in this mode often describe their activities as part of their personality. Their objective is focused on enlightenment and it is often described as a personal choice motivated by a wish to educate citizens in scientific rationality. Rather than representing a specific area of 
expertise, these scientists represent science as that institution in society which produces truth, and they seem to regard their own role as a kind of guardian for this institution. When science communication is done in this mode, communication professionals are not seen to be helpful at all, rather they are perceived as an unnecessary barrier between the scientists and the citizens. Journalists are often also perceived in the same way as problematic intermediaries that simply distort the communication process. Because this mode of communication is closely linked with personality it is not perceived as a set of skills that can be acquired as part of professional training, but rather as an individual ethos that is gained partly by experience and partly by choice. In this context, the research leaders seem to perceive of themselves as an example that their younger staff can choose to follow, if they are so inclined.

The third mode is communication on behalf of the research organization, for instance the research centre or the entire university. When communicating in this mode the focus is on branding in relation to the organization's stakeholders. Scientists communicating in this mode are very aware of the necessity of creating external legitimacy in order to attract resources and funding and their aim is to represent their university as a professional research organization. To this aim they often find it useful to have professional communication expertise available and they will readily use it, although they do sometimes criticize the professional quality of the assistance. Scientists who primarily reflect on communication in this mode tend to consider communication skills as part of a set of managerial competencies that young researchers need to learn in order to develop into independent research leaders. Several of these informants are also arguing that the acquisition of these skills cannot be left to chance, but has to be systematically obtained through professional training.

When reviewing the interviews, the specific Danish tradition of engagement and dialogue does not seem particularly pertinent. The culture of anti-elitism poses problems for several of these research leaders. They are indignant about a culture that does not seem to value their competencies and does not seem to share their values of using scientifically produced knowledge as basis for decisions. However, another part of the informants seem to enjoy the Danish debate culture and feel it is a necessity that also experts are challenged to give reasons for their judgements. In general, research leaders from the biotech area are most at ease with the idea of public engagement with science. It is therefore tempting to conclude that the fact that many of them have been engaged in public controversies for several decades has influenced their attitude. In comparison, the nanotechnologists in the present sample - whose background is primarily physics and chemistry - generally seem less willing to entertain the idea that the public should take part in the governance of science.

\section{Conclusion}


The Danish model of participatory governance in science and technology is founded upon a cultural tradition of dialogue. Based upon their experiences of a common life and a sense of shared destiny, citizens are expected to engage in deliberation with the aim of identifying consensual solutions on the common good. Communication of science and technology has been part of this general movement of shaping competent citizens through deliberation, but it has always had a distinctive anti-elitist flavor. Within this tradition, citizens have always had a moral right to question the testimony of authorities and to counter it with their own experiences of ordinary life. The deliberation tradition has been institutionalized in bodies like the Board of Technology and has gained attention outside Denmark as inspiration for moves towards dialogical and participatory forms of science communication.

During the last decade, however, the Danish model has been in decline in Denmark. A new government turned the focus away from participatory technology assessment towards innovation as a driver for the knowledge economy and rebooted the tradition of science communication. In the new millennium, science communication is predominantly perceived as a process of dissemination which is intended to enhance the public understanding of science and technology.

\section{References}

Agersnap, T. (1992). Konstruktiv teknologi. København: Nyt fra Samfundsvidenskaberne.

Agersnap, T., Jakobsen, G., \& Kempinski, J. (1984). Konsensuskonferencer i danmark. København: DSI.

Andersen, l., \& Jæger, B. (1999). Danish participatory models. scenario workshops and consensus conferences: Towards more democratic decision-making. Science and Public Policy, 26(5), 331-340.

Cronberg, T. (1995). Do marginal voices shape technology? In J. Simon, \& J. Durant (Eds.), Public participation in science: The role of consensus conferences in europe (pp. 125-134). London: Science Museum.

Einsiedel, E. F., Jelsøe, E., \& Breck, T. (2001). Publics at the technology table: The consensus conference in Denmark, Canada, and Australia. Public Understanding of Science, 10(1), 83-98. 
Gregory, J., \& Miller, S. (1998). Science in public. communication, culture, and credibility. New York: Plenum Trade.

Grundtvig, NFS (1839) 'Er Lyset for de Lærde Blot' (Is the Light Just for the Learned?), The Danish Folk High School Song Book, 17. edition, song number 462 (Odense: Foreningens Forlag).

Horst, M. (2008). In search of dialogue: Staging science communication in consensus conferences. In D. Cheng, M. Claessens, T. Gascoigne, J. Metcalfe, B. Schiele \& S. Shi (Eds.), Communicating science in social contexts (pp. 259-274) Springer.

Horst, M. (under review) The discipline, the organization, or science itself? Working paper, unpublished.

Horst, M., \& Irwin, A. (2010). Nations at ease with radical knowledge. Social Studies of Science, 40(1), 105126.

House of Lords select committee on science and technology. (2000). Science and society. The united kingdom parliament.

Irwin, A., \& Wynne, B. (1996). In Irwin A., Wynne B. (Eds.), Misunderstanding science?. Cambridge: Press Syndicate of the University of Cambridge.

Joss, S., \& Durant, J. (1995). Public participation in science. London: Science Museum

Kappel, K., \& Lykkeskov, A. (2007). Etik i tiden : 20 år med det etiske råd. Det Etiske Råd.

Klüwer, L. (1995). Consensus conferences at the danish board of technology. In S. Joss, \& J. Durant (Eds.), Public participation in science: The role of consensus conferences in europe (pp. 41-49). London: Science Museum.

Knudsen, T. (2001). Da demokrati blev til folkestyre: Dansk demokratihistorie I. Akademisk Forlag A/S. 
Koch, L., \& Horst, M. (2007). Fra almenhed til pluralitet: Forestillinger om konsensusskabelse i det etiske råds historie. In K. Kappel, \& A. Lykkeskov (Eds.), Etik i tiden: 20 år med det etiske råd (pp. 143-166). København: Det Etiske Råd.

Korsgaard, O. (2004). Kampen om folket - et dannelsesperspektiv på dansk historie gennem 500 år. København: Gyldendal.

Kragh, H., Kjærgaard, P. C., Nielsen, H., \& Nielsen, K. H. (2008). Science in Denmark : A thousand-year history. Århus: Aarhus University Press.

Lassen, J. (2004). Changing modes of biotechnology governance in denmark. STAGE Discussion paper 3. Retrieved 13/11 2011, from http://www.stageresearch.net/STAGE/documents/3_BiotechnologyGovernanceDK_final.pdf

Lund, A. B., \& Horst, M. (1999). Den offentlige debat - mål, middel eller mantra. København: Fremad.

Mejlgaard, N. (2009). The trajectory of scientific citizenship in Denmark: Changing balances between public competence and public participation. Science and Public Policy, 36(6), 483-496.

Rasmussen, A. F. (2002). Prime minister's new year's speech. Retrieved 13/11, 2011, from http://www.stm.dk/Index/dokumenter.asp/ p 7354.html

Seifert, F. (2006). Local steps in an international career: A Danish-style consensus conference in Austria. Public Understanding of Science, 15(1), 73-88.

STAGE (2005). Science, Technology and Governance in Europe - website and final report. STAGE network, retrieved 13/11 2011 from http://www.stage-research.net/STAGE/index.html. 
Suine, K., \& Mejlgaard, N. (2001). Public understanding of science - perceptions of and attitudes toward biotechnology in Denmark. Aarhus: Analyseinstitut for forskning.

Videnskabsministeriet (2004). Forsk og fortæl. Ministeriet for Videnskab, Teknologi og Udvikling.

Videnskabsministeren (2011). Universitetsloven. Retsinformation, retrieved 13/11 2011 from https://www.retsinformation.dk/forms/r0710.aspx?id=137835

Vikkels $\varnothing$, S. (2003). Electronic patient records and medical practice reorganization of roles, responsibilities, and risks; electronic patient records and medical practice reorganization of roles, responsibilities, and risks. København: Samfundslitteratur.

'All quotes from Danish sources have been translated by the author. 